pressure to shallow dome shape, and were tested for load-bearing properties and stability at slight, continuously maintained pressures. Neither unsymmetrical loading on sheet steel models up to $12 \mathrm{ft}$. in diameter nor wind-tunnel tests disclosed undesirable features.

Besides theoretical studies of stress and strain distribution in the membrane, construction features and experience obtained with actual pressuresupported roofs were investigated. One of these structures was a semi-cylindrical roof, $25 \mathrm{ft}$. radius, $200 \mathrm{ft}$. long, built of 22-gauge sheet steel on formwork which was supplanted by $0.5 \mathrm{lb}$. per sq. in. air pressure after the ends were closed with a flexible connexion and the floor rendered airtight. This structure was built in 1934 at Minneapolis and was used as a 70,000-bushel grain bin for a year, after which it was dismantled because grain dust in suspension constituted an explosion hazard. Another structure investigated was a series of flexible-roofed inflated gas holders built of thin steel plates up to $300 \mathrm{ft}$. in diameter.

Because air-supported roofs offer enormous spans with the minimum of structural materials, they have caused considerable interest. The aeroplane manufacturer, Glenn L. Martin, proposed an 800-ft. diameter roof for a football stadium at Baltimore in 1945, shortly before the construction of amusement structures was forbidden by the U.S. Government. This roof was to have been of 52-SO aluminium alloy $0 \cdot 109 \mathrm{in}$. thick with welded seams, and was to be supported by $0.06 \mathrm{lb}$. per sq. in. (gauge) air pressure maintained by ordinary ventilating fans discharging into the enclosure formed by the walls and ground. Entrance and exit were to be by revolving doors, and means were included for raising the pressure to balance snow loads and to supply power in case of power failure. The roof membrane was to be anchored to a concrete compression ring around the periphery of the stadium having sufficient strength to withstand the inward pull of the membrane to its yield strength. The membrane was to be formed by air pressure to finished shape from a somewhat flatter constructed shape. This would relieve stresses in the welded seams and tight spots in the membrane, and constitute a proof test of the structure. The air pressure to do this was calculated to be about $0 \cdot 22 \mathrm{lb}$. per sq. in., a pressure of small physiological importance, and one obtainable with the ventilating blowers. This pressure would be about that needed to support $2.5 \mathrm{ft}$. of snow; and the roof capable of containing this pressure would also be capable of withstanding the lifting effect of a wind velocity of 125 miles an hour. These figures were based on the experiments previously mentioned. It was also found with a flutter model in the wind tunnel that a slight excess pressure maintained in the structure prevents rippling or flutter of the roof.

A number of other buildings using this roof have been considered, although none, so far, has been built. These include smaller structures about $300 \mathrm{ft}$. in diameter in which the circular anchor ring is carried overhead on columns and the building space extended underneath to fill out the corners of the lot. Structures ranging upwards to $1,800 \mathrm{ft}$. in diameter for industrial buildings, storage warehouses, commercial and amusement structures where clear span and low cost were important factors have been investigated. It was discovered that such structures could probably be built over the poorest of soils, since the roof loads were evenly transmitted to the floor and not concentrated at the footings. Another factor of interest is that positive pressure within the structure precludes outside air leakage into the building, making exceptional control of the interior atmosphere possible.

A weatherproof transparent plastic of possible use for these roofs is being developed in the United States. If the material, now in pilot-plant construction, is satisfactory, the utility of these roofs would be enormously extended. An unofficial group in Washington, D.C., is investigating the use of a transparent roof over a central courtyard surrounded by a block of apartments for human habitation, and following a suggestion of Prof. J. D. Bernal, a group in Salt Lake City, Utah, is investigating its possibilities for the growing of plants in waterless areas where the moisture may be conserved by the roof. The possibilities of extending the food-growing areas of the world by a technique involving little more than the cost of the plastic and the anchoring means might be of great importance. Likewise the possibility of inexpensively separating large areas from the prevailing atmosphere, and rendering them climatically inhabitable, may have considerable effect in the tropics.

A British Patent 591985 has been allowed on this construction and is endorsed Licence of Right.

\section{PRODUCTION OF AN ANTIBIOTIC SUBSTANCE ON WHEAT STRAW AND OTHER ORGANIC MATERIALS AND IN THE SOIL}

\author{
BY ERNA GROSSBARD \\ Experimental and Research Station, Cheshunt
}

$\mathrm{M}$

ANY soil micro-organisms produce under artificial conditions antibiotic substances which inhibit the growth of certain plant pathogens. On the assumption that a similar process may take place in the soil, investigations on this problem were com menced at the Research Station, Cheshunt, and an attempt made to devise a method whereby antibiotic substances will be produced abundantly in the soil for the purpose of controlling soil-borne diseases. Blair ${ }^{1}$, Garrett ${ }^{2}$, Millard and Taylor ${ }^{3}$, West and Hildebrand 4 , Sanford ${ }^{5}$, and others, have reported that organic manuring reduced the incidence of certain soil-borne diseases and have suggested that microbial antagonism may be one of the important factors.

Our experiments here have shown that certain micro-organisms known to produce antibiotic substances on synthetic media, such as Aspergillus clavatus, Aspergillus terreus, Penicillium patulum and Streptomyces antibioticus, will do so when grown on autoclaved wheat straw to which water has been added ${ }^{6}$.

Penicillium patulum has been studied in detail, because patulin (clavacin), the antibiotic substance produced by it, has a considerable inhibitory effect on the growth of certain plant pathogens ${ }^{6,7,8,8}$. The organism grew well on sterilized soil, but aqueous soil extracts did not inhibit the growth of the test organisms Bacterium coli, Bacillus mycoides and Bacterium phytophthorum. An antibiotic substance was formed, however, when the fungus was grown on sterilized wheat straw, bracken and sugar beet 
TABLE 1

\begin{tabular}{|l|c|}
\hline \multicolumn{1}{|c|}{ Medium } & $\begin{array}{c}\text { Diameter of area of inhibition } \\
\text { (mean to nearest mm.) }\end{array}$ \\
\hline Straw and water & 20 \\
Straw and water and $3 \cdot 5 \%$ & 27 \\
glucose & 29 \\
Sugar beet waste and water & 17 \\
Bracken and water glucose & 27 \\
and water $3 \cdot 5 \%$ glucose & \\
\hline
\end{tabular}

waste. The addition of glucose $(3.5$ per cent by weight) increased the inhibitory action of the wheat straw and bracken cultures. The undiluted culture fluid was assayed by the cylinder plate method. The plates were bulk-seeded with a 1:10 suspension of B. mycoides.

Among plant pathogens inhibited by the culture fluid of $P$. patulum grown on wheat straw and water were $B$. carotovorum, $B$. aroidece, $B$. phytophthorum and several species of Phytophthora. There are indications that a number of other phytopathogens are also sensitive.

Autoclaved composted wheat straw when inoculated with $\boldsymbol{P}$. patulum gave an antibiotic substance only in the presence of glucose. This also applied to peat, and to some extent to fescue, lucerne, mustard and sainfoin. Without glucose, cultures on the four latter materials gave inconsistent results varying with the sample used. In general, the inhibitory agent appeared to be rather unstable. Fescue gave the best results.

Experiments were then made to determine whether an antibiotic substance could be produced within the soil. Fresh wheat straw, 5 per cent, and water, 50 per cent by weight, were mixed with oven-dried soil, autoclaved and inoculated with $P$. patulum. After incubation the liquid expressed from the soil was assayed against $B$. coli, $B$. mycoides and $B$. phytophthorum by the cylinder plate method. It completely inhibited the growth of the test organisms.

A decrease in the quantity of wheat straw reduced the inhibitory action on the test organisms, while the addition of glucose greatly increased it. When straw was omitted and glucose ( 2 per cent) added, figures were only slightly lower than those obtained, for example, from a soil, straw $(2 \cdot 5$ per cent) and glucose (2 per cent) medium (see photograph, Table 2).

It appears that carbohydrate decomposition is an essential factor for the production of an antibiotic

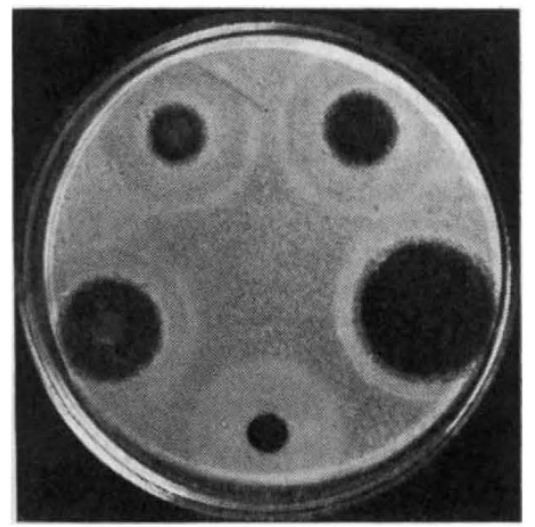

VARIATIONS IN THE ZONES OF INHIBITION. CYLINDERS WERF FILLED WITH SAMPLES OF MEDIA $a-e$ (TABLE 2 ). AN UNDILUTED SUSPENSION OF $B$. mycoides WAS USED. NOTE ALSO ZONES OF STIMULATED GROWTH
TABLE 2

\begin{tabular}{|c|c|c|}
\hline Medium & $\begin{array}{c}\text { Inhibition of } \\
\text { B. mycoides } \\
\text { (1:10 suspension) }\end{array}$ & $\begin{array}{l}\text { Diameter of area } \\
\text { of inhibition }\end{array}$ \\
\hline $\begin{array}{l}\text { (a) Soil and water } \\
(b) \text {," , and } 2 \cdot 5 \% \text { straw } \\
(c) \text {, and } 5 \% \text { straw } \\
\text { (d) Soil, water and } 2 \% \\
\text { glucose } \\
(e) \quad \text {, ", and } 25 \% \text { straw } \\
(f) \quad, \text { and } 5 \% \text { straw }\end{array}$ & $\begin{array}{l}\text { None } \\
\text { Partial } \\
\text { Complete } \\
\text { Complete } \\
\text { Complete } \\
\text { Complete }\end{array}$ & 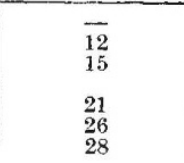 \\
\hline
\end{tabular}

substance in sterilized soil by $P$. patulum. A sterilized medium loam such as was used in this experiment may be an adequate substratum for the growth of the fungus; but it does not provide the conditions necessary for the production of an antibiotic sub. stance. Yet as a matter of precaution it should be said that the absence of an inhibitory agent in the liquid expressed from the soil is not conclusive evidence that the antibiotic substance has not been formed at all. At low concentrations adsorption may take place. Garrett, West and Hildebrand, and Sanford have found that the addition of glucose to the soil decreased the incidence of certain diseases. These workers suggested that glucose effected a favourable modification of the microflora of the soil.

Glucose or other sources of carbohydrates such as wheat straw appear to be necessary for the manufacture of an antibiotic substance by $P$. patulum, at least in sterilized soil. It is tentatively suggested that, apart from altering the microflora, glucose may, in addition, induce the production of antibiotic sub. stances in the soil not only by $P$. patulum but also by other micro-organisms.

This work has been carried out with a grant from the Agricultural Research Council. I am greatly indebted to Dr. W. F. Bewley, director of the Experimental and Research Station, Cheshunt, for guidance and advice.

${ }^{1}$ Blair, I. D., Ann. Appl. Biol., 30, 118 (1943).

2 Garrett, S. D., Ann. Appl. Biol., 25, 742 (1938).

${ }^{3}$ Mil ard, W. A., and Taylor, C. B., Ann. Appl. Biol., 14, 202 (1927). - West, P. M., and Hildebrand, A. A., Canad. J. Re8., (C), 19, 199

- Sanford, G. B., Soil. Sci., 61, 9 (1946).

'Grossbard, E., Rep. Exp. Res. Sta. Cheshunt, 55 (1945); 41 (1946) and $(1947)$, in the press.

' Gilliver, K., Ann. Bot., N.S., 10, 271 (1946).

${ }^{8}$ Smith, G., Trans. Brit. Mye. Soc., 31, 136 (1947).

'Waksman, S. A., et al., Bull. Torrey Bot. Club, 71, 107 (1944).

\section{SEISMOLOGICAL RESEARCH IN GREAT BRITAIN}

$\mathrm{T}$ HE report of the British Association Seismological Committee to Section A (Mathematics and Physics) at the Dundee meeting in September 1947 covers a wide field of work during the period 1942-47.

During the war years, much of the time of the staffs of British seismological stations was devoted to war work. At Kew the three Galitzin instruments and the short-period vertical seismograph were maintained continuously. The Wood-Anderson seismographs were discontinued in May 1942, but were restarted for the Heligoland explosion of April 18, 1947. One of these is to be sent on loan to the Royal Observatory, Helwan. The analysis of seismograms is complete to date, and the Kew monthly bulletin, discontinued in May 1940, is being restarted. During the War, information on the recording of flying bomb 